\title{
A(s) Florbela(s) de Agustina Bessa-Luís: biografismo, desmistificação e remitificação em Florbela Espanca, a vida e a obra
}

\author{
Jonas Leite*
}

\section{Labirinto sem linha de Ariadne: Agustina e seu biografismo sui ge- neris}

Agustina Bessa-Luís exerce papel de relevo na literatura portuguesa: em mais de cinquenta anos ininterruptos de escrita, transitou pelo romance (gênero pelo qual mais enveredou), teatro, biografia, literatura infantil, além de crônicas, memórias e textos ensaísticos. É consenso na crítica literária especializada que seu romance A Sibila (1954) demarca uma transição, ao lado de Vergílio Ferreira, na história do romance contemporâneo português. Segundo Ana Paula Arnaut (2002, p. 71), ao citar Álvaro Manuel Machado, A Sibila inaugura um universo totalmente novo, não só em Portugal, mas naquele cenário do romance europeu, pois "o trabalho que ambos exercem sobre a linguagem [Agustina e Vergílio], sobre o modo de narrar, terá fortes ressonâncias nas novas gerações, vindo a provocar o surgimento de uma ficção sui generis, nas décadas de 70 e 80" (GoMEs, 1993, p.31).

A faceta biógrafa da escritora compõe-se de cinco textos: Santo António (1973), Florbela Espanca, a vida e a obra ${ }^{1}$ (1979), Sebastião fosé (1981), Longos dias têm cem anos - presença de Vieira da Silva (1982), Martha Telles: o castelo onde irás e não voltarás (1986). Além disso "há outros três livros que poderiam constar sob o título genérico de biografia: Adivinhas de Pedro e Inês [1983], A monja de Lisboa [1985] e Um bicho da terra (1985)" (Filizola, 1998, p. 119-120). ${ }^{2}$ De todo modo, Agustina

- Doutor em Literatura e Interculturalidade e professor do Departamento de Letras da Universidade Federal de Pernambuco (UFPE), Recife, PE, Brasil. E-mail: jonasleite@hotmail.com.

1 Segundo Anamaria Filizola, "há duas tiragens desta edição, ambas em 1979. Na edição da Arcádia consta a dedicatória ‘À meu irmão’, que não aparecerá na que será publicada em 1984, pela Guimarães Editores, com o título de Florbela Espanca, com reproduções de fotografias (em menor número na edição da Guimarães), algumas cartas de Florbela e a seleção de alguns sonetos" (FIlizola, 200o, p. 169). Neste trabalho, todas as referências são da edição de 1984, mas à referência ao título do livro permanece igual ao da primeira edição, ou seja, Florbela Espanca, a vida e a obra, por ter sido o seu título original.

2 Ainda segundo Anamaria Filizona "há que se destacar uma 'protobiografia', só recentemente colocada na 'bibliografia activa da autora' que consta do livro Camilo - o génio e a obra. É um texto escrito a duas mãos sobre o banqueiro Arthur Cupertino de Miranda, proprietário do Banco 
centrou a dimensão biográfica de sua obra em personalidades da cultura, política e artes portuguesas - o que aparentemente parece óbvio, mas se pensarmos, por exemplo, que uma das biografias sobre Clarice Lispector foi escrita por um estadunidense, Benjamin Moser, ou que uma espanhola, Concepción Delgado Corral, escreveu uma das tantas biografias sobre Florbela Espanca, Florbela Espanca: asa no ar erva no chão (2005), entenderemos que essas escolhas não passam necessariamente por um critério de conterraneidade.

As biografias nascem, assim, de uma necessidade humana subjetiva de fixação frente à transitoriedade da vida. Através da escrita, o indivíduo biografado vence o tempo e permanece na história, porquanto "o objetivo macro da narrativa biográfica é gerar conhecimento sobre o passado de alguém ou de alguma coisa" (VILAs BoAs, 2002, p. 21), criando a expectativa nos leitores de um material em que será possível inteligir sobre os fatos aventados pelo biógrafo, a respeito da vida do biografado.

Neste diapasão, Lejeune (2008), ao discutir questões inerentes à autobiografia, propôs o entendimento sobre a formulação de um pacto entre leitor e biógrafo, espécie de contrato tácito, no qual o leitor assume a veracidade daquilo que o biógrafo escreveu. Na maioria das vezes, esse "acordo" é acompanhado de uma certa necessidade de afirmação de um discurso global, visão de um todo, pormenorizada, acerca do ser objeto das biografias. Por isso, são comuns expressões como "biografia total" ou até mesmo "biografia definitiva". Nessa esteira de pensamento, "publicar uma biografia, anunciá-la como tal e não como um romance é prometer fatos verídicos, pois o biógrafo deve ao leitor, acima de tudo, a verdade" (MAURoIs, 1932 apud Dosse, 2009, p. 59), sendo esta advinda de pesquisa em fontes primárias, secundárias e até terciárias, todavia com a compreensão de que o biógrafo "jamais concluirá a sua obra, não importa o número de fontes que consiga exumar" (Dosse, 2009, p. 14).

Em se tratando da pesquisa empreendida, Agustina cumpre a contento esse "mandamento" biográfico, dando-nos a ler um texto que é prenhe de dados e informações de diversas naturezas, na tentativa de apreender o ser multívoco que foi e se tornou Florbela Espanca: a obra da poetisa, principalmente os poemas, a correspondência travada entre amigos e familiares, referências a estudos biográficos anteriores (O drama de Florbela Espanca, de Amélia Vilar, de 1947), estudos críticos (sobretudo o Estudo Crítico, de José Régio, de 1950, mas também o prefá-

Português do Atlântico, que integra uma publicação comemorativa dos 50 anos da criação do Banco (1919-1969) O texto, que conta a história de Cupertino de Miranda entremeada com a história do Banco, não é assinado, e o nome de A. Bessa-Luís consta nos créditos como tendo sido a organizadora da iconografia. No entanto, o estilo é inequívoco, podendo-se identificar sem problemas as partes escritas pela outra pessoa, que segundo me esclareceu a Autora, é um economista, responsável pelas partes sobre a política econômica do Banco. É de supor que se trate de um texto encomendado, que somado ao fato de ser escrito a duas mãos o coloca num segundo plano com relação às demais obras. Para um estudo sobre a biografia agustiniana, todavia, é necessário levá-lo em consideração" (FilizolA, 200o, p. 44). 
cio de Guido Battelli e Júlia Alves à edição de fragmentos de cartas da poetisa, publicada em 1931 e o Nótulas Florbelianas, de Lopes Rodrigues, publicado em 1956), pesquisa em documentos de cartório, notícias de jornais, depoimentos de pessoas que conheceram a poetisa, dados históricos, impressões regionais, além de colecionar um pequeno acervo de fotos no livro e uma antologia poética e epistolar. ${ }^{3}$ Tudo isso concorre para lastrear as diversas (e até divergentes) conclusões que a biógrafa vai chegando a respeito de Florbela.

Ela conhece, claro, muito mais do que isso: a biografia elaborada por Celestino David (1949), as cartas de Florbela lacradas por Guido Battelli na Biblioteca Pública de Évora, tendo compulsado certamente outros vários e muitos textos tais como o Florbela Espanca, de Carlos Sombrio (1947) e assim por diante. Através de Agustina, ficamos sabendo até que a filha de Alberto Moutinho, primeiro marido da poetisa, se dedicava (sem muito espírito, aliás) à obra da ex-esposa do pai (DAL FARRA, 2017, p. 02).

Por outro lado, engana-se quem acreditar que esse traço pesquisador e curioso de Agustina testifica a escrita de uma biografia dentro de padrões mais ou menos preestabelecidos para aquilo que se fixou minimamente a respeito desse gênero. É claro que, em textos biográficos, há uma flexibilização de formas e conteúdos, pois é um gênero propício à invenção, mesmo que se lide, a todo tempo, com um referente real - "o recurso à ficção no trabalho biográfico é, com efeito, inevitável na medida em que não se pode restituir a riqueza e a complexidade da vida real" (Dosse, 2009, p. 55). Portanto, podemos afirmar que estamos diante de uma narrativa híbrida, equilibrada entre a realidade e a ficção, pois "a biografia não depende apenas da arte: quer-se também estribada no verídico, nas fontes escritas, nos testemunhos orais" (Dosse, 2009, p. 59).

No entanto, é comum nas biografias, mesmo as mais preenchidas pela ficção, a observância a uma coerência interna, espécie de linha de verossimilhança que dá suporte ao trabalho do biógrafo e atende (ou intenta atender) às expectativas do leitor. Disso decorre a importância das interpretações do biógrafo às passagens vivenciais do biografado. Por exemplo, a despeito da tese de que Florbela faleceu de edema pulmonar ser praticamente desacreditada pelos estudiosos da escritora, Maria Alexandrina, na pequena biografia Florbela Espanca e sua personalidade (1964), assevera que a causa mortis da poetisa foi, de fato, a assentada no laudo assinado

\footnotetext{
3 Segundo Maria Lúcia Dal Farra, "as primeiras edições do Diário do Último Ano e d'O Dominó Preto, bem como os respectivos prefácios de Natália Correia (1981) e de Yvette K. Centeno (1982), são posteriores e, portanto, zona ainda não franqueada aos olhos da romancista, apenas com exceção de alguns contos desta derradeira obra, que ela parece ter lido, seja no manuscrito original, seja na publicação do Portugal Feminino, datada de 1930 [...]. Refiro-me aos contos "À margem de um soneto", "Carta da Herdade", "Os mortos não voltam", publicados em Lisboa pela revista Portugal Feminino, respectivamente nos números 2 (março de 1930), 5 (junho de 1930) e 6 (julho de 1930)" (DAL FARRA, 2017, p. 02).
} 
pelo carpinteiro Manuel Alves de Souza. ${ }^{4}$ Isso se coaduna com o tom laudatório e positivista difundido ao longo daquele texto, pois Alexandrina, no papel de biógrafa, para além das possíveis contestações que podem ser levantadas no seu trabalho, concebe uma Florbela romantizada, agindo pelo impulso do amor e da saudade, livrando-a da "culpa" de qualquer detratação que venha a ter sofrido. Nessa concepção, morrer em decorrência de uma patologia, dá ao texto coerência em vista do pensamento que lhe orienta e estrutura. De toda sorte, foi uma resposta a um fato da vida da artista, mesmo que regida por um patente discurso panegírico.

Em Florbela Espanca, a vida e a obra, Agustina faz diferente: mantém o texto com a aparência de uma biografia, age como biógrafa, inclusive refletindo acerca da recepção e poder dos textos biográficos, "a decadência da biografia deu-se quando o que há de paixão no pathos social, a sua vida espiritual, foi substituído pelo infantilismo pedagógico da nossa época" (BEssA-Luís, 1984, p. 44), mas implode por dentro as estruturas do gênero. Os dados biográficos estão embaralhados, sem nenhuma obediência a uma cronologia linear. O tempo da narrativa oscila sem prévias contextualizações e, principalmente, é dada mais de uma versão para um mesmo fato. Tal feito, "desvirtua" a concepção de biografia, que, em tese, visa dar ao leitor a "verdade", ou melhor, a interpretação de uma "verdade" dos fatos. É um tipo de leitura que não se pode presumir, pois "o leitor de Agustina deve se habituar a ter suas certezas desestabilizadas. Penetrar em um de seus livros é caminhar em um labirinto, onde muitos caminhos, tidos como possíveis saídas, levam a novos labirintos" (Oliveira, 2009, p. 153).

Não obstante essa característica se destacar como elemento do engenho literário e, por isso, ser vista como parte do estilo da autora, Eugénio Lisboa (1981), em recensão crítica da biografia, defende que não se trata de estilo, mas de uma espécie de "erro" procedimental, em virtude da justificativa de que as biografias têm dentre "as suas condicionantes inescapáveis, um certo número de regras metodológicas e deontológicas que não se podem iludir - e que Agustina Bessa-Luís [...] totalmente ignora ou despreza" (LisboA, 1981, p. 92). Por isso, o texto de Agustina sobre Florbela sofreria de um "problema de incompatibilidade que é, quanto a nós, insolúvel” (LisBoA, 1981, p. 92). Eugénio Lisboa entende que o fato do livro pertencer a uma coleção com fitos específicos (o homem e a sua obra), esta vincula o modelo a um escrito que tenha um mínimo de coordenadas para ajudar o leitor (Cf. LisBoA, 1981, p. 92), ou seja, uma linha cronológica mais ou menos linear e uma representação mais objetiva, que não desse tanto espaço à divagação.

Todavia, Agustina captura Florbela, muitas vezes, a partir de um ponto de vista hermético, dificultando a compreensão de um leitor que desconheça totalmente a

\footnotetext{
4 A despeito de Mário Lage ser médico e ter, em tese, a capacidade de atestar a causa mortis de alguém, a declaração de óbito de Florbela Espanca, como se pode verificar no fac-símile do registo de óbito da poetisa, publicado na Fotobiografia organizada por Rui Guedes (1985, p. 231), foi incrivelmente assentada por Manuel Alves de Souza, um carpinteiro que passava na rua no momento e descobriu a morte da escritora.
} 
poetisa. Há na obra de Florbela um verdadeiro elogio a certos signos linguísticos tomados como símbolos, como as imagens que retratam as mãos: "As minhas mãos outrora carinhosas/ Pairavam como pombas" (EsPANCA, 1996, p. 175); ou as que se referem aos olhos: "meus olhos andam doidos por te olhar!/ Cega-me com o brilho dos teus olhos" (EspancA, 1996, p. 74). Agustina aproveita isso, mas dentro de uma chave ininteligível em um primeiro momento:

Em Florbela, a simbologia dos olhos tantas vezes cantados e das mãos continuamente elogiadas não deixa dúvidas quanto à sua natureza andrógena "Sou eu! Sou eu! A que nas mãos ansiosas/prendeu da vida, assim como ninguém, / os maus espinhos sem tocar nas rosas". Toda uma teoria de sublimação está definida nestes versos (BESSA-Luís, 1984, p. 80).

De fato, Agustina subverte aquilo que se poderia conceber como as regras canônicas do biografar, o que não se apresenta como um desserviço, mas como um efeito de estilo, uma estratégia eficaz, sobretudo na difícil tarefa de retratar alguém afeito ao uso de máscaras e truques de ilusão de ótica: já que todo ser humano é incapturável, Agustina se recusa a engendrar Florbela por um só ponto de vista (Cf. DAl FArRA, 2017, p. 12). Agustina divide a biografia em três capítulos, sem especificar um critério temporal ou até mesmo evidenciar épocas específicas da vida de Florbela: em todas as partes são retomados momentos semelhantes, sob os mais diferentes prismas e mediante infindáveis idas e vindas no tempo. Catherine Dumas (1997, p. 195) aventa a possibilidade dessas três secções serem uma referência aos três casamentos de Florbela ou às características destacadas por José Régio no estudo de 1950 (narcisismo, donjuanismo e hermafroditismo psicológico), todavia, essas elucubrações se sustentam quando da aplicação de um possível simbolismo às partes do livro, pois elas não se subdividem nem subsistem pela divisão dos tempos dos casamentos ou das características aventadas por Régio. Nos três capítulos todas essas questões estão diluídas e, mais de uma vez, referenciadas.

Seja como for, os capítulos fornecem um perfil fragmentário da poetisa, longe do maniqueísmo e da binaridade que, por vezes, abundam em muitas biografias. A título de exemplo, Agustina faz referência à estreia poética de Florbela nos jornais: "Florbela começa a publicar versos no Notícias de Évora em julho de 1916" (BEsSA-Luís, 1984, p. 46), em seguida comenta o lançamento do seu primeiro livro, "quando em 1919 o Livro de Mágoas é publicado, Bela é presa do desespero do estreante" (BESSA-Luís, 1984, p. 46), na sequência imediata, há um recuo temporal e muda-se totalmente de assunto: "em setembro de 1912 tinha Florbela dezessete anos e estava na Figueira da Foz em casa dos padrinhos” (BEssA-Luís, 1984, p. 47). Atente-se para o fato de não haver uma tessitura de linearidade no tempo, é o leitor quem precisa ir montando o quebra-cabeça biográfico. Outra coisa, é o expediente comum que faz com que referências à mesma época ou aos mesmos fatos apareçam mais de uma vez no texto, como se a cada nova alusão aos mesmos episódios, eles fossem vistos por lentes diferentes. 
Casam-se em 1913. Data dessa altura um dos seus mais belos retratos. [...] Em 8 de dezembro de 1913 casa-se pela primeira vez em Vila Viçosa. [...] Florbela Espanca nasceu a 8 de dezembro, casou-se pela primeira vez a 8 de dezembro, e morreu a 7 de dezembro exactamente às dez horas da noite (BESSA-Luís, 1984, p. 21, 53, 105).

Além disso, "um mesmo fragmento de carta ou de soneto pode aparecer várias vezes, em contextos diversos, para diversos objetivos, independente da época em que foi escrito" (Oliveira, 2009, p. 154). Corroborando os aspectos aludidos há pouco e implicando uma escrita biográfica singular, uma vez que a mecânica biográfica não se perfaz de forma retilínea, mas de forma labiríntica e circular, pois um mesmo assunto, como já aventado, pode voltar à tona sempre de outra maneira, como uma nova interpretação.

Para além dessas subversões relativas ao gênero biográfico, outro aspecto, ainda nessa mesma perspectiva, talvez seja mais radical: Agustina elenca diversas explicações e/ou percepções para narrar um mesmo acontecimento, contrariando a noção de um pacto implícito entre biógrafo e leitor, na medida em que não será apresentada a versão do fato, mas versões, inclusive não necessariamente complementares. A título de exemplo, Agustina ventila três possibilidades diferentes para a morte de Apeles:

O suicídio de Apeles não pode ser confirmado senão através dessa linha sinuosa que é a da intuição, a única que não conhece renúncias. Eram frequentes nessa época desastres como o que o vitimou. Porém, já foi dito, que não há acaso nas catástrofes; até quando parte uma perna, o homem exprime nisso a sua vontade. $\mathrm{O}$ estado de alma de Apeles era turbulento, perdera a misteriosa noiva e, sobretudo, perdera a irmã. Ela já se casara duas vezes, mas não com a avidez sentimental que dava mostras agora (BEssA-Luís, 1984, p. 127).

Não. De facto, não se pode afirmar que Apeles se suicidou. A proeza de Gago Coutinho e Sacadura criara a mística da raça cujas caravelas já não se chamam mais $S$. Gabriel, mas Lusitânia. Não têm velas latinas, mas as asas dum Fairey 16. Os rapazes ansiavam por produzir acções espetaculares. Alguns sucumbem, pela fragilidade do material do voo, pela precipitação das manobras, pelo desejo de serem únicos e sem confrontação no arrojo. Possivelmente Apeles largou um dia por cima do Tejo, sem outra intenção senão a de experimentar o aparelho e voltar para beber chá com algumas amigas. Mas não volta. O seu rosto salpicado de óleo fica para sempre mergulhado na água. Viaja submerso até o mar profundo e não volta mais (BESSA-Luís, 1984, p. 129).

O que se passou com Apeles foi decerto um desses enigmas cujas razões estão tanto no mundo interior como no mundo exterior da pessoa. O ser humano produz o seu próprio desastre e a sua própria salvação. Quando 
uma águia deixa cair uma telha que levava no bico, na cabeça de um sábio da Grécia, cumpre-se um oráculo que previra que ele morreria no desmoronamento de uma casa. Possivelmente, ele não deixou de pensar mais nisso, e dormia ao ar livre, mas sem abandonar a ideia da morte, a ponto de ela se tornar a sua cara companheira. O mundo exterior é instrumento da nossa intenção profunda. Todo o ser humano vive enredado numa teia inextrincável de autopunição que lhe evita um obscuro e denso mal-estar em que o próprio ato de viver se encontra compreendido. Apeles não planeou nada quando levantou voo sobre a barra do Tejo; mas, naturalmente, no mais fundo de si mesmo, tudo estava decidido (BessA-Luís, 1984, p. 135).

Agustina assevera, na primeira versão da morte de Apeles, que o irmão da poetisa se matou e ventila para tal fato uma motivação de cunho sentimental, pois Florbela teria encontrado, enfim, um marido que a compreenderia e, com isso, o caçula perderia a exclusividade do sentimento amoroso da irmã. Em seguida, na versão modificada, é apresentada a possibilidade de uma tragédia, ocorrida na singularidade de mais um voo-treino do piloto. Esses dois argumentos são trazidos de forma binária e excludente - suicídio ou acidente, plano ou catástrofe. No entanto, mais à frente, a biógrafa lança mão de uma nova versão que, de certa maneira, aproxima as duas anteriores.

Anamaria Filizola destaca ainda que a biógrafa apresenta diversas versões para a morte da poetisa e todas as hipóteses se somam para explicar o suicídio, mas sem a resolução concreta: "neurose de abandono, bovarismo, desgosto amoroso, frustação intelectual, desejo de evasão para um sono profundo, e não para a morte, choque anafilático decorrente de incompatibilidade medicamentosa" (FilizolA, 1995, p. 78). De igual modo, Eugénio Lisboa (1981) observou que a autora da biografia aventa três possibilidades para o matrimônio de Florbela:

Dão-se, no mesmo livro, e para o mesmo facto (o casamento de Florbela) três explicações diferentes e que mutualmente se liquidam. [...] a primeira explicação é hipotética ("é possível”); a segunda é já mais categórica ("Soror Saudade é símbolo"); a terceira é francamente categórica ("os casamentos não passam da tentativa"). E o pior é que não vemos modo de conciliar a fuga à liberdade intelectual da primeira hipótese ou a fuga ao prazer da segunda com o experimentalismo lúdico da terceira (LisBOA, 1981, p. 93).

Assim, se o objetivo convencional de uma biografia é dar ao leitor a "verdade" dos fatos, Agustina vai na contramão, deixando ao leitor a tarefa de criar o seu trajeto para sair dos labirintos que adentrou quando da leitura, escolhendo os caminhos e as análises que desejará encetar a partir das múltiplas visões oferecidas. O efeito prático é que isso pode provocar uma frustação em um leitor mais ávido por traçar um panorama retilíneo sobre a vida e a obra da poetisa, mas, por outro lado, as singularidades dessa biografia podem ser encaradas por um viés 
instigante, configurando um desafio de ir se perdendo e se encontrando nos labirintos construídos por Agustina, sem uma linha de Ariadne para ajudar a achar o caminho de saída. O fio condutor é, justamente, dentre as Florbelas erigidas por Agustina, seguir o caminho da desmistificação ou adentrando a trilha da remitificação ou, até mesmo, construindo uma ponte para unir esses dois territórios procedimentalmente diversos.

Outro aspecto também merece destaque na maneira de biografar tecida por Agustina Bessa-Luís é a influência da forma do romance, notadamente seus aspectos não canônicos e ficcionais. À altura do lançamento de Florbela Espanca, a vida e a obra Agustina já era uma romancista reconhecida no cenário literário português. Por causa dessa faceta e do patente engenho ficcional engendrado no texto, o livro foi saudado pela crítica literária como uma espécie de biografia romanceada. Eugénio Lisboa (1981, p. 92), ao se reportar a Norman Mailer, conhecido romancista americano, que escreveu a vida de Marilyn Monroe, afirmou: "É possível que não haja instrumento mais apto à captura da qualidade errática do que um romance. Lance-se um ladrão na pista de outro ladrão e um artista na pista de outro artista" (MAIler, 1973 apud LisboA, 1981, p. 92). Ventila-se, assim, a possibilidade de um artista retratar outro artista, como justamente acontece no texto ora debatido, e que isso poderia ser a chave para uma compreensão do ser biografado, mas com o perigo de se "fazer demasiado romance e menos biografia" (LisBOA, 1981, p. 92).

A estratégia de Agustina de criar vários núcleos de análise e ir costurando-os (sem um critério aparente) faz surgir um uso constante do recurso à ficção, com a tessitura textual prototípica do gênero narrativo. "Um dia viu a rainha de perto, no Paço do Reguengo, e impressionou-a, não a individualidade, mas o que a interpreta: a seda, o colar, a tiara. Florbela pediu à madrasta um vestido de seda e teve-o; assim como o colar de oiro, e o anel, a châtelaine" (BESSA-Luís, 1984, p. 9). Nesse trecho, a dimensão extremamente subjetiva, na qual a criança se impressiona mais com os objetos que metonimizam a rainha do que com a figura da própria, e, ao ter esses objetos, metaforicamente, atinge, para si, o mesmo status real, mistura-se a uma forma mais apegada ao ato de biografar, "quase tudo o que se escreveu sobre Florbela e sobre muitos outros está impregnado dessa falta de profundidade que a função social deseja, como meio de iludir as paixões" (BESSA-Luís, 1984, p. 44). Logo,

Agustina vai privilegiar as possibilidades romanescas e a carga poética que o diagnóstico da vida em si contém. Quer isto dizer que a personagem se coloca inteiramente à mercê do olhar clínico, frio, perscrutador e desapaixonado da biógrafa que, neste como noutros casos, não deixa de acumular as funções de romancista. Efectivamente, Florbela Espanca é um texto que [se] beneficia de um estatuto híbrido, porquanto nele se amalgamam materiais de providência e índole diversa (NEves, 1997, p. 208). 
A própria Agustina, certamente tendo a dimensão que seu texto hibridiza formas do romance e da biografia, esclarece que aquele tem um caráter mais lúdico e que este é mais imbrincado do exercício de apreender uma realidade factual, nas suas mais diversas facetas, pois o biógrafo torna-se como a consciência de um povo.

Em geral aceita-se melhor o romance do que a biografia. Ao romance atribui-se sempre a invenção. Esta goza duma popularidade, de tudo aquilo que se destina a servir o ócio e não ao estudo. A biografia inquieta um pouco; não é excitante como um espetáculo. Na leitura do romance está implícita a escusa de toda a meditação; o novelista aceita presidir a uma assembleia recreativa, enquanto o biógrafo, esse tem que ser o juízo e até a imprecação de todo um povo. Por isso a sua obra tem mais de incógnito do que a do romancista (BESSA-Luís, 1984, p. 44).

Com efeito, a biografia estaria mais ligada a uma faceta da ordem do verídico. "Há biógrafos austeros, que se posicionam radicalmente em favor de uma indicialidade jacobina: só acreditam no documento (se possível, com firma reconhecida)" (Pignatari, 1997, p. 16), enquanto o romance estaria mais ligado ao trabalho inventivo, na estilização, grosso modo, dos elementos narrativos (tempo, espaço, narrador, enredo e personagem). Assim, "o romancista goza de liberdade; o biógrafo está manietado" (Woolf, 1976 apud Dosse, 2009, p. 62). Todavia, é possível que o biógrafo dose a parcela de ficção e a parcela factual de seu texto, erigindo um gênero híbrido (uma biografia romanceada) pela justaposição das características típicas de cada um desses gêneros, em oposição, por exemplo, a uma biografia "fortemente indicial" (Cf. Pignatari, 1997, p. 17). São, dessa maneira, "biografias marcadamente simbólicas, mais verbalistas do que verbais” (Pignatari, 1997, p. 17).

À vista disso, Agustina Bessa-Luís executa uma junção de aspectos da biografia somados a aspectos do romance, criando uma potência ímpar para o livro debatido, pois aquilo que a biografia não poderia dar é franqueado pelo romance, haja visto que "o biógrafo tem uma deficiência com relação ao romancista na medida em que não pode evocar a vida interior da sua personagem. Falta-lhe as fontes que lhe permitiram penetrá-la, ao passo que o romancista sempre dá largas à fantasia" (Dosse, 2009, p. 59). O reverso também é possível, justamente pela noção de "verdade" que é vista como um atributo das biografias e como faltante aos romances.

Dessa maneira, as subversões e características elencadas acerca da biografia Florbela Espanca, a vida e a obra tornam o biografismo de Agustina sui generis, na medida em que desestabiliza padrões e certezas, espécie de ponto de fuga ante um didatismo não deliberado e metaforizado na figura de um labirinto, onde o próprio leitor precisa ordenar o puzzle e erigir para si a sua linha de Ariadne que lhe guiará pelos meandros construídos por Agustina. 


\section{A(s) Florbela(s) de Agustina Bessa-Luís: desmistificação e remitifi- cação}

Agustina não queria escrever sobre Florbela. Convidada pela editora Arcádia para biografar a poetisa, não dera resposta definitiva, até que, segundo narra Maria Lúcia Dal Farra (2017, p. 3), em um telefonema por engano, um homem pergunta à Agustina se era "Bela" quem falava. Foi uma espécie de sinal de que a biografia deveria ser escrita. Como se fosse o gesto empático que faltava para se alcançar a dimensão afetuosa inerente aos trabalhos dessa natureza: "para dizer a verdade sobre alguém é preciso amar esse alguém. Só então se pode amar a verdade que ele personifica" (BessA-Luís, 1984, p. 125).

"Transforma-se o amador na cousa amada", diz o soneto de Camões, e à Agustina foi preciso, portanto, ver-se como "Bela" para poder escrever a respeito de "Bela", sintetizada por Catherine Dumas (1997) como "certa dose de narcisismo para chamar a si o objecto biografado, dando assim a sua contribuição para a história das metamorfoses recíprocas do amante e do ser amado" (DumAs, 1997, p. 20o). Com efeito, Agustina tece uma complexa rede de fios da qual a personagem Florbela é o centro das urdiduras.

No afã de apreender alguém demasiado diversificado e com uma história de vida deveras singular, são criados núcleos temáticos que vão se encaixando para formar o tecido narrativo sobre Bela. Para tanto, a biógrafa remonta a história do Alentejo, inclusive em uma perspectiva mítica dos primeiros povos célticos que habitaram a região; inventa a genealogia e os meandros familiares da poetisa; implica com biografias e biógrafos anteriores; ${ }^{5}$ penetra em dimensões extremamente subjetivas, na medida em que via a poetisa como alguém que tem "fome de tristeza, mais do que satisfação" (BEssA-Luís, 1984, p. 39) e da qual não escampam conclusões vacilantes e deterministas, pois "todo o comportamento de Florbela não pode ser dissociado de sua aparência depressiva” (BessA-Luís, 1984, p. 178). Para além disso, revela particularidades, descobre detalhes, reporta as vicissitudes da família, denuncia os interesses capitalistas de João Espanca, que só vai perfilhar a poetisa anos depois de morta, bem como a mesquinharia de Mário Lage, que nunca patrocinou nenhuma edição dos livros da esposa e quando ela morreu, assinou os volumes e, por óbvio, lucrou com isso as artimanhas editoriais de Guido Battelli, ao criar uma verdadeira campanha de marketing para divulgar os poemas de Florbela, chegando ao ponto de alterá-los e usando o mesmo expediente em cartas. Tudo isso é disposto para analisar o trajeto de Florbela à luz dos lugares diferentes em que morou (Vila Viçosa, Évora, Lisboa, Porto, Redondo), fazendo juízo crítico sobre a obra da poetisa, além de uma autoanálise sobre sua experiência de biógrafa.

5 Para Agustina, "muita coisa do que se tem dito de Florbela está marcada por essa ausência de espírito que reduz toda a estrutura da realidade a uma dimensão mesquinha, semelhante a um estado de pânico" (BESSA-LUÍS, 1984, p. 160), em referência à Amélia Vilar e até ao próprio Guido Battelli. 
Enfim, Agustina faz uma espécie de blitzkrieg sobre o terreno da história de Florbela Espanca, "atacando" todos os possíveis elementos que fazem parte desta fábula, sem poupar ninguém (inclusive a própria Florbela) daquilo que considerou passível de crítica. É possível citar como exemplo, " a maneira como os homens se postaram em volta dela, mais como curiosos que como amantes" (DAL FARRA, 2017, p. 4), para criar um painel no qual se representa a multiplicidade de uma mulher plural, com acento nas muitas idiossincrasias típicas do ser humano, notadamente as de Florbela Espanca. Diante disso, a biografia em destaque "alia o exercício de uma subjectividade quase ilimitada, isto é, o direito de interpretar e organizar de forma significante os fragmentos de um todo desconexo, com a assunção de uma plena soberania criativa” (NEvEs, 1997, p. 210).

Até a escrita da biografia de Agustina, os livros que biografavam Florbela eram macerados pela tendência à grandiloquência ou ao reducionismo e diziam muito mais da necessidade de heroicizar ou diminuir a trajetória de vida da artista portuguesa. Por mais que todos esses textos, minimamente, destacassem as qualidades literárias da poetisa, eles vibravam ao som de conjecturas convencionais.

Alfredo Reguengo, em ensaio publicado dois anos após a morte da poetisa (Florbela Espanca, 1932), tece uma rede de elogios para combater, principalmente, o falatório provocado pelo suicídio da escritora e admite as máscaras utilizadas poeticamente por ela. Em tom laudatório, como sendo expressão da verdade e da realidade afirmou que "os seus livros são a mais completa autobiografia que ela poderia escrever" (Reguengo, 1932, p. 9). Nessa mesma esteira, Maria Alexandrina (Florbela Espanca e sua personalidade, de 1964) pinta uma Florbela resignada e elevada no caráter e no agir, seguindo o trilho que busca acentuar suas qualidades poéticas para diminuir as detratações imputadas à poetisa: "Florbela era simples, afectuosa, despida de artifícios e tinha por vezes a graciosidade fácil das crianças" (Alexandrina, 1964, p. 12). Por outro lado, Amélia Vilar ( $O$ drama de Florbela Espanca, de 1947) retrata Florbela por características físicas negativas, afirmando que a escritora era desprovida de beleza e, sobretudo, fazendo recair sobre ela insinuações acerca de seu comportamento sexual: "cigarro queimado, outro aceso, numa canseira febril de quem porfia em se reduzir a cinzas, num desafio activo com determinado advogado, com banca no Porto, para o qual o próprio terceiro marido de Florbela Espanca saíra a comprar Addullas" (ViLAR, 1947, p.13).

Todos esses fragmentos demarcam o lugar binário que os estudos críticos e biográficos, com raras exceções (destacamos, obviamente, José Régio e Jorge de Sena), ocupavam no cenário florbeliano, pois "quase tudo o que parece importar a respeito de Florbela é se ela era recomendável para entrar na família de qualquer negociante de panos" (BESSA-Luís, 1984, p. 16o). De toda sorte, apesar de que "quase tudo o que se escreveu sobre Florbela e sobre muitos outros está impregnado dessa falta de profundidade que a função social deseja, como meio de iludir as paixões" (BESSA-Luís, 1984, p. 44), cumpriam o papel de colocar a figura de Florbela no panteão dos mitos literários, justamente pelas contradições que encerravam, dentro 
de uma ótica de defender ou acusar a poetisa acerca da sua obra e da sua biografia, marcadas mais pela subjetividade dessas ações do que por um senso crítico.

Ademais, em todos esses momentos, apesar do recurso à ficção estar acessível e intrinsicamente ligado ao trabalho com a linguagem, Florbela não era personagem, era objeto de estudo, sujeito de afirmações de toda sorte. Agustina, dentro de um terreno fronteiriço biografia/romance, constrói Florbela como uma personagem regida pela perspectiva de um narrador onisciente, curioso e perscrutador, dotado de uma clarividência capaz de penetrar no âmago da alma da personagem. "Cada um dos casamentos de Florbela agrava o seu mal, produz um novo surto de perversão, que são seus versos” (BEssA-Luís, 1984, p. 92, grifos da autora), pois, para Agustina, mesmo que a poesia seja a mola de salvação de Florbela, há nela o gérmen que traduz e retrata a sua neurose.

Esse narrador, em algumas ocasiões, apresenta-se transmutado na figura da biógrafa-autora, em um mecanismo que comporta uma máscara da própria Agustina Bessa-Luís. Segundo Maria Lúcia Dal Farra (1978), ao examinar as proposições de Kayser (1958) e Booth (1970) acerca da ficção, destaca a figura de um "narradorimplícito", que mascara a figura do autor:

Manejador de disfarces, o autor, camuflado e encoberto pela ficção, não consegue fazer submergir somente uma sua característica - sem dúvida - a mais expressiva - a apreciação. Para além da obra, na própria escolha do título, ele se trai, e mesmo no interior dela, a complexa eleição dos signos, a preferência por determinado narrador, a opção favorável por esta personagem, a distribuição da matéria e dos capítulos, a própria pontuação, denunciam a sua marca e a sua avaliação (DAL FARRA, 1978, p. 20).

Em Florbela Espanca, a vida e a obra, em certos momentos, o narrador funde-se à figura da biógrafa-autora, que faz considerações em torno do ato de biografar (por exemplo, ao não saber algum dado ou comentar o estado de documentos manejados). A apreciação desses aspectos adensa o entendimento de que a separação entre autor e narrador é, em dados momentos, bastante tênue. Essa peculiaridade acentua o caráter híbrido do texto, na medida em que testifica o seu caráter investigativo e, por outro ângulo, cria uma atmosfera típica da ficção, pois enseja um preenchimento de lacunas. No que pese as citações em demasia, vale a comprovação dos expedientes de um narrador transmutado na figura da biógrafa-autora:

Um pouco adiante, não distante da Porta dos Nós, que dá acesso a "ilha” do Paço, há a vereda do outeiro de S. Bento, donde Vila Viçosa se vislumbra inteira como um lençol lavado estendido ao sol. Não sei se Florbela aí subiu com as amigas de escola e se alegrou nos terraços da tijolaria dum moinho que há ali (BESSA-Luís, 1984, p. 28).

Muito se discutiu se a morte de Florbela foi suicídio ou aquele edema pulmonar que lhe valeu um enterro cristão e algumas dúvidas da vizinhança. A declaração de óbito foi feita por um certo Manuel Alves de 
Sousa, carpinteiro. O estado dos arquivos em Portugal é tão deficiente que só a minha investigação do caso de Florbela motivou o averbamento da sua morte no registro de casamento, em 25 de Janeiro de 1978 (BESSA-Luís, 1984, p. 158).

Por sua vez, a personagem erigida por Agustina é sempre passiva. É a voz da biógrafa-autora quem vai, na composição dos núcleos temáticos, construindo os diferentes quadros narrativos da vida de Florbela. A personagem só "fala" por meio de excertos de cartas e poemas, que Agustina propositalmente não referencia, para, possivelmente, criar uma atmosfera advinda de um argumento de autoridade, já que são as próprias palavras da poetisa confirmando a voz dominante na narrativa. É um exercício retórico. Esse descolar e colar de frases, em virtude das novas conotações que a mudança de espaço e de contexto podem provocar, mistura, portanto, realidade e ficção em um terreno movediço, onde não se define ao certo aquilo que é da biografia e aquilo que é do romance. Tal fato se depreende da dimensão subjetiva que a biógrafa erigiu (ao asseverar, por exemplo, que Florbela destrói as imagens amorosas que a rodeiam) e confirmar essa impressão pela voz da própria poetisa, na colagem de um excerto da lavra de Florbela:

O abandono destrói sistematicamente os objectos que ama, para assim atingir a imagem daquilo que o desiludiu. A vida de Florbela está cheia de imagens amáveis que ela se compraz em destruir. Gosta de se desvalorizar para se fazer querer: "Sou uma criatura vulgarmente educada, vulgarmente inteligente, vulgarmente cultivada. Tudo vulgar, querida, tudo!” (BessA-Luís, 1984, p. 122).

No processo de composição da personagem, Agustina faz referência explícita ao estudo de José Régio (1950), no qual o autor percebe Florbela através das lentes do que nomeou de "caso humano". "A sua poesia é dos nossos mais flagrantes exemplos de poesia viva. Quero dizer que toda ela nasce, vibra e se alimenta do seu muito real caso humano; do seu porventura demasiado real caso humano" (RÉGIO, [1950] 2010, p. 7 - grifos do autor), destacando que a obra da poetisa orbitava em torno de três palavras-chave: narcisismo, donjuanismo e hermafroditismo psicológico. Tal mote é aproveitado por Agustina a partir de uma visada biográfica, para traçar, talvez, o centro irradiador do seu livro, em um modo muito particular (por vezes, determinista) de olhar: perceber Florbela como um ser humano enredado pelas suas vivências pessoais, vítima de uma neurose, mas que soube transcender pela poesia e, consequentemente, salvar-se de si.

Justamente a metáfora do albatroz de Baudelaire, aludida no início do terceiro capítulo, "as grandes asas impedem o albatroz de caminhar em terra" (BEsSA-Luís, 1984, p. 125). Florbela, na compreensão daquela biografia, era um ser complexo e devastado pela neurose que lhe atingia as diversas camadas, mas, como escritora, fazia grandes voos. O olhar desapaixonado de Agustina, consubstanciado no contínuo processo de desmistificação da poetisa, intentado ao longo de todo aquele 
livro, não "contamina", portanto, a percepção da genialidade poética de Florbela e, mais de uma vez, a biógrafa acentua isso

Florbela é um dos mais admiráveis poetas nossos de todos os tempos. [...] Todo o soneto ["Espera”] é extraordinário de autoridade soberana e doce - faz de Bela um expoente indiscutível na história da poesia (BEssA-Luís, 1984, p. 134, 42).

Nesse diapasão, "a biografia de Bessa-Luís produziu sem dúvida uma nova imagem de Florbela: a de um ser condicionado pelas suas vivências pessoais, ser esse que se desdobra na poetisa genial, cuja poesia se dirige ao inconsciente colectivo" (Alonso, 1997, p. 227). Esse pensamento inaugural reflete uma tendência que deu a tônica à biografia de Agustina e que é bastante diminuta nos estudos florbelianos anteriores. A tentativa de compreensão daquela personalidade dentro de uma chave humana, com tudo o que isso acarreta: medos, qualidades, motivações de ordens múltiplas, errâncias. Enfim, hipóteses, tentativas temáticas de singularizar o plural e, afinal, capturar e fixar, pela escrita, a essência humana de uma pessoa, como demanda um trabalho de Argos, com cem olhos abertos à diversidade da vida.

Para apreender Florbela sob um prisma humano, Agustina despe-a do caráter mítico constituído até então e começa a trilhar um caminho de desmistificar a escritora: os discursos sedimentados sobre uma mulher incompreendida, sobre um alguém à frente do seu tempo, sobre um aludido comportamento imoral, a construção de um perfil relativo à visão de uma poetisa imolada à morte, tudo isso é implodido pela biógrafa, ao ponto máximo de desmentir à própria poetisa. "Florbela descreve-se como uma velha, fala nos seus cabelos brancos. E, no entanto, quando procedem à sua exumação e o corpo é transladado para Vila Viçosa, a cabeleira famosa apresenta-se cor de ébano e cheia de vida" (BESSA-Luís, 1984, p. 82).

Na relação de Florbela com o pai, depurada por costumes tradicionais do Alentejo, onde, para Agustina, havia um ambiente menos afeito ao preconceito, em certa medida, explica a predisposição de Florbela às aventuras sentimentais (o que lhe legou a pecha de imoral, mas também a de mulher corajosa, à frente da época que vivia), uma espécie de herança de João Espanca que irá lhe acompanhar, com as consequências disso, pelo resto da vida. Assim, Florbela é "apenas" uma mulher, fruto de consequências culturais e familiares, sem a aura mítica que costuma acompanhar a sua persona. Logo, remontar a infância da poetisa, compreender as circunstâncias e os atores que circulam o seu nascimento e crescimento, é lançar luz sobre a Florbela adulta e adentrar as mais profundas camadas daquela psiquê, de modo que se torna possível traçar o mosaico multifacetado de um gênio literário, em torno do qual se afirma um padecimento por conta de uma doença subjetiva, genericamente chamada de neurose, estendida também a um complexo de abandono. 
A vida de Florbela é um tratado de decomposição lúcida. Ela exerce medidas repressivas contra um terror que esvazia de toda a substância o seu mundo exterior. Esse terror provém do laço mágico que é a cólera do pai, mensagem recebida no inconsciente e que se traduz na visão dum universo de miasmas insuportáveis (BEssA-Luís, 1984, p. 37).

Porém, o leitor não pode se fiar, por exemplo, no estereótipo do poeta romântico, de chofre, pois Agustina remata: "Florbela não é uma poetisa romântica; as suas angústias são problemas lógicos" (BESSA-Luís, 1984, p. 10). Em outro momento, dispara "Florbela nunca foi incompreendida" (BESSA-Luís, 1984, p. 67). Todas essas passagens revelam o intento de descolar da poetisa um invólucro mítico, dado a falta de profundidade dessas narrativas que alçaram Florbela a um patamar de mito literário, mas que soçobraram em imagens estereotipadas e divergentes entre si.

Nesse processo desmistificador, a compreensão se volta inúmeras vezes à camada inconsciente do ser que, segundo a psicologia, pode inclinar o indivíduo a diversas situações, e Agustina vai tecendo uma série de argumentos de cunho psicológico. Dentro dos núcleos temáticos, a saber, a relação familiar, as complexidades da sua personalidade, o trabalho literário, a questão dos relacionamentos amorosos, o contexto histórico e cultural, as impressões da própria biógrafa. Resvalando a face de um determinismo um tanto quanto perigoso, porque não se sustenta pelos elementos aduzidos, apesar de poder, hipoteticamente, ser verdade. Por exemplo, a memória de que a mãe de Florbela, Antónia Lobo, foi uma criança pobre e que, por isso, entregara Florbela à madrasta e ao pai, explica o argumento de que, por ter sido abandonada pela mãe, Florbela tenderia, sendo mãe, a abandonar também a criança. A biógrafa veda a maternidade à Florbela em uma tripla sanção: biológica, física e moral. É o caso emblemático de um determinismo atávico que, infelizmente, Agustina fez muito destilar em seu texto:

A mãe de Florbela fora já uma criança carenciada, e por isso entregara tão facilmente a filha a mãos adoptivas; mais tarde abandonara o filho, num brusco movimento de rejeição. O ciclo do abandono só se fecha com a esterilidade de Florbela ou com a sua falta de idoneidade moral e física para a maternidade (BESSA-Luís, 1984, p. 127).

Agustina também expande o processo desmistificador a outros elementos cristalizados sobre a escritora. $\mathrm{O}$ caso da data precisa da morte da poetisa, que teria tirado a própria vida no dia em que cumpria o seu trigésimo sexto aniversário, alimentou e ainda alimenta o imaginário de uma morte ritualística, como se fosse o encerramento de um ciclo e (quem sabe?) o início de outro. "Na noite de 7 de Dezembro, Florbela ritualiza o quod vide da inexorabilidade cíclica do arquétipo lunar que a possui, morrendo no dia do aniversário do seu nascimento"(CORREIA, 1981, p. 27). "Na passagem de 7 para 8 de dezembro, precisamente às duas horas 
da madrugada do dia 8 , à hora exata em que nasceu e no dia que completava 36 anos de idade, Florbela morre em virtude de uma overdose de barbitúricos" (DAL FARRA, 2012a, p. 75). Mas, para a biógrafa, a morte foi às dez horas da noite do dia 7 de dezembro ${ }^{6}$ (BESSA-Luís, 1984, p. 105) e o dia do funeral foi o dia de seu aniversário, contrariando as tantas imagens aproveitadas para a composição ficcional de uma Florbela vibrando em um limiar "vida-morte", em uma hora final que antecede seu aniversário, como se depreende, por exemplo, da novela As duas faces do dia, de Dora Nunes Gago, publicado pela Chiado Editora em 2013. A novela apresenta duas personagens, Florbela e Brígida, vivendo momentos decisivos entre o dia 7 e 8 de dezembro, de 1930 e 2012, respectivamente. A primeira caminha para a morte e a segunda tenta sair da morte iminente para a vida. "Num puzzle de sintéticas analepses, apresenta-se a vida de duas mulheres, separadas 82 anos, Florbela e Brígida, enjauladas na existência: a uma pesam-lhe memórias de perdas, a outra procura memórias que perdeu, ambas ouvem os relógios ímpios, vigilantes e decisórios, porém enquanto Florbela fixa os olhos na tumular parede branca do quarto, Brígida fixa os olhos nos cortinados brancos, indicador de destinos distintos" (Couto, 2013, p. 5-6).

Atrelado a isso, desfaz-se também a imagem de "infeliz poetisa" tão difundida por Battelli e aproveitada por tantos outros críticos. Para Agustina, Florbela morre "não porque está infeliz, mas porque se tornou magnânima" (BESSA-Luís, 1984 , p. 81), ventilando, portanto, um feixe de coincidências por proximidades de datas, mas sem a efabulação que uma morte no próprio dia do aniversário (sobretudo um suicídio) poderia causar.

Por fim, nessa seara de desmistificações, o assunto de um possível incesto entre Florbela e Apeles é tratado sem tabu, no sentido de não o admitir como experiência física e concreta. "Houve quem explicasse pelo incesto a veemência quase pungente com que Florbela tratou sempre o irmão. Porém, há nessa veemência um sentido muito posterior aos pressupostos do incesto e que chega às mais profundas modulações do despeito" (BEssa-Luís, 1984, p. 36). É, novamente, a linha de explicação psicologizante que demonstra o conjunto de (rel)ações da poetisa, seguindo o compasso que desliga o caráter mítico (e, por isso, tantas vezes maniqueísta) para a ascensão de uma personagem de traços humanos, por isso vacilante e múltipla.

A ânsia de narrar Florbela sem o rótulo mítico acaba por criar um efeito de rebote consubstanciado em um outro processo, o da remitificação. Para além das associações de Florbela às figuras míticas (as origens célticas, a Dama do Lago e Lancelot, Eva, Lilith, o próprio mito literário de Madame Bovary ${ }^{7}$ ) há um expediente

\footnotetext{
Rui Guedes (1986, p. 79) afirma que a partir de depoimento colhido por Milburgues Ferreira, a hora do falecimento foi calculada para às $22 \mathrm{~h}$ do dia 7 de dezembro de 1930, por conveniências do horário do enterro. Portanto, a hora exata da morte da poetisa permanece em suspenso.

7 Agustina, ao longo da biografia, deslinda a origem céltica do Alentejo. Também metaforiza a relação de Florbela e Apeles com a da Dama do Lago e Lancelot, em dado momento vai compara Florbela a Eva no viver e a Lilith na escrita e, dentre as versões que dá ao seu suicídio, ventila o bovarismo como motivação.
} 
mais refinado, porque sutil, de realocar Florbela no caminho mítico que, por diversas vezes, Agustina fez questão de desviar. O recurso já foi debatido, o efeito não: é o viés de penetrar nas camadas psicológicas da personagem para lhe sondar as motivações e, assim, remontar seu percurso. Tal ação que se mostra a serviço da desmistificação também serve, por via reversa, ao processo de remitificação. Ao fim, a imagem vislumbrada é a de uma mulher compreendida nos paradoxos típicos do ser humano, mas delineada por um traço mítico, como uma rendição ou reconhecimento àquilo que se combatia. Dessa maneira, há uma ambivalência de imagens que se complementam e se contrastam: espécie de "acordo íntimo/como a mão direita e a esquerda", conforme pontuou Fernando Pessoa (2006, p.55), em contexto diverso ao de agora.

Tudo isso, pode ser novamente compreendido pela metáfora do albatroz aplicada à Florbela por Agustina: as grandes asas atrapalham a ave em terra, mas lhe proporcionam, pela envergadura e potência, um voo ágil, capaz de cobrir grandes distâncias sem grandes esforços. Assim, a poetisa envolta em uma neurose, deambulava em relações amorosas e em contextos familiares conturbados, vivendo uma vida simples e longe da fama (que no futuro a tomou). No entanto, a sua ânsia artística lhe propiciou o condão mítico, tornando-a singular por isso. "Primitiva, Florbela tenta obter, por intermédio do elemento mágico da poesia, protecção contra o mundo exterior. Escreve versos como os primeiros homens desenhavam os caracteres rupestres" (BESSA-Luís, 1984, p. 20). Nos outros aspectos, era igual a toda gente. A poesia é a chave que permite o acesso a outro mundo. É, justamente, a história do bardo, metáfora inicial que Agustina recorre para situar Florbela:

Esta é a história dum bardo. Se situarmos Bela nesse corpo neutro onde se dá a passagem do sonhador para a realidade, compreenderemos não só os seus versos como toda a obscuridade das formas-pensamentos que os inspiraram. [...] Um poeta canta a existência que ele encarna; mas a sua canção é, como o tempo do bardo, desencarnada. [...] Toda a vida de Bela decorre entre o perigo do afecto, da ligação com as pessoas e as coisas; e tenta furtar-se a elas pela fixação num objecto, que é a sua forma poética. [...] A arte de morrer é a operação do poeta (BESSA-Luís, 1984, p. 8).

Assim sendo, ao repetir Régio, "a interpretação de Florbela mais penetrante que conheço é a de José Régio. 'Que dados temos para assegurar que Florbela viveu o que escreveu?'” (BEssA-Luís, 1984, p. 24), Agustina demarca a inscrição de dois polos: uma Florbela mulher (desmistificada) e uma Florbela poetisa-gênio (mitificada). A ponte que une esses dois loci é a morte, compreendida pela biógrafa como o leitmotiv da vida e da poesia de Florbela.

\section{Referências}

Alexandrina, Maria. Florbela Espanca e a sua personalidade. Conferência lida na Câmara Municipal de Vila Viçosa, em 9 de dezembro de 1964. 
Alonso, Cláudia Pazos. Imagens do eu na poesia de Florbela Espanca. Lisboa: Imprensa Nacional - Casa da Moeda, 1997.

Arnaut, Ana Paula. Post-Modernismo no romance português contemporâneo: fios de Ariadne; máscaras de Proteu. Coimbra: Almedina, 2002.

Bessa-Luís, Agustina. Florbela Espanca. Lisboa: Guimarães Editores, [1979] 1984.

Correia, Natália. Prefácio. In: Espanca, Florbela. Diário do último ano. Edição facsimilada com um prefácio de Natália Correia. Lisboa: Bertrand, 1981.

Couto, Teresa Sá. A voz na dobra do tempo. In: GAGo, Dora Nunes. As duas faces do dia. Lisboa: Chiado Editora, 2013. p. 05-06.

Dal Farra, Maria Lúcia. O narrador ensimesmado: o foco narrativo em Vergílio Ferreira. São Paulo: Ática, 1978.

Dal Farra, Maria Lúcia. A Florbela de Agustina. Labirintos: Revista eletrônica do núcleo de estudos portugueses, Feira de Santana, n.1, p. 1-13, 2017.

Dal Farra, Maria Lúcia. Florbela, a inconstitucional. In: Espanca, Florbela. Afinado desconcerto: contos, cartas, diário. Estudo introdutório, apresentações, organização e notas de Maria Lúcia Dal Farra. São Paulo: Iluminuras, 2012. p. 11-77.

Dosse, François. O desafio biográfico: escrever uma vida. São Paulo: EdUSP, 2009.

Dumas, Catherine. Florbela visitada por Agustina: a mulher poeta e os mitos. In: A planície e o abismo (Actas do Congresso sobre Florbela Espanca realizado na Universidade de Évora, de 7 a 9 de dezembro de 1994). Évora: Vega, 1997. p. 195-204.

Espanca, Florbela. Poemas. Estudos introdutórios, organização e notas de Maria Lúcia Dal Farra. São Paulo: Martins Fontes, 1996.

Filizola, Anamaria. Notas de leitura: Florbela Espanca, de Agustina Bessa-Luís ou para amar Florbela. Boletim do Centro de Estudos Portugueses forge de Sena, n. 7, Araraquara, p. 61-79, jan-mar, 1995.

Filizola, Anamaria. Agustina Bessa-Luís e Inês de Castro: nem história nem ficção. In: IAnNone, Carlos Alberto; GOBI, Márcia V. Zamboni; Jungueira, Renata Soares (Orgs.). Sobre as naus da iniciação: estudos portugueses de literatura e história. São Paulo: Editora UNESP, 1998. p. 119-134.

Filizola, Anamaria.O cisco e a ostra: Agustina Bessa-Luís biógrafa. 2000. 320f. Tese (Doutorado em Teoria Literária) - Instituto de Estudos da Linguagem, Universidade Estadual de Campinas, Campinas, 2000.

Gago, Dora Nunes. As duas faces do dia. Lisboa: Chiado Editora, 2013.

Gomes, Álvaro Cardoso. A voz itinerante. São Paulo: Edusp, 1993.

Guedes, Rui. Fotobiografia. Lisboa: Publicações Dom Quixote, 1985. 
Guedes, Rui. Acerca de Florbela. Lisboa: Publicações Dom Quixote, 1986.

Lejeune. Philippe. O pacto autobiográfico: de Rousseau à Internet. Belo Horizonte: Editora UFMG, 2008.

LisBOA, Eugénio. Recensão crítica a 'Florbela Espanca : a Vida e a Obra, de Agustina Bessa-Luís. In: Revista Colóquio/Letras. Recensões Críticas, n. ${ }^{\circ}$ 6o, Mar. 1981, p. $92-94$.

Neves, Margarida Braga. Florbela Espanca ou a revelação da personagem. In: $A$ planície e o abismo (Actas do Congresso sobre Florbela Espanca realizado na Universidade de Évora, de 7 a 9 de dezembro de 1994). Évora: Vega, 1997. p. 205-214.

Oliveira, Paulo Motta. Entre gêneros, sem certezas: Florbela e Pascoaes sob o olhar prismático de Agustina. In: Fernandes, Annie Gisele; Silveira, Francisco Maciel (Orgs.). A literatura portuguesa: visões e revisões. Cotia: Ateliê Editorial, 2009 .

Pignatari, Décio. Para uma semiótica da biografia. In: Hisgail, Fani (Org.). Biografia: sintoma da cultura. São Paulo: Hacker Editores, 1997. p. 13-19.

RÉGIO, José. Estudo crítico. In: EspancA, Florbela. Sonetos. Rio de Janeiro: Bertrand Brasil, 2010.

Reguengo, Alfredo. Florbela Espanca. Separata do n. 96 de "A Aurora do Lima" de 9 de dezembro de 1932.

Vilas-BoAs, Sergio. Biografismo: reflexões sobre a escrita da vida. São Paulo: Editora UNESP, 2002.

Vilar, Amélia. O drama de Florbela Espanca. Porto: Costa Carregal, 1947.

Recebido em 11 de novembro de 2020.

Aprovado em 8 de abril de 2021.

\section{Resumo}

A(s) Florbela(s) de Agustina Bessa-Luís: biografismo, desmistificação e remitificação em Florbela Espanca, a vida e a obra

\section{Jonas Leite}

Agustina Bessa-Luís exerce papel de relevo na literatura portuguesa: com mais de cinquenta anos ininterruptos, transitou pelo romance, teatro, biografia, crônicas, memórias, textos infantis e trabalhos ensaísticos. Da sua faceta biográfica, destacase a publicação de Florbela Espanca, a vida e a obra (1979), livro que alia um biografismo bastante peculiar aos moldes de um romance, criando não uma Florbela 
Espanca biografada, mas diversas Florbelas, rompendo, assim, a lógica do biografismo tradicional. No presente trabalho objetiva-se compreender o percurso criativo de Bessa-Luís ao traçar um perfil biográfico para Florbela Espanca, tendo em conta que, neste trajeto, a desmistificação da poetisa portuguesa é uma característica patente nesta obra, mas também que a remitificação é o resultado da conjunção de elementos biográficos e ficcionais colecionados por Bessa-Luís para a realização do livro em relevo.

Palavras-chave: literatura portuguesa, Florbela Espanca, biografismo, mitificação, remitificação. 